\title{
Proposal for a Software Architecture as a Tool for the Fight Against Corruption in the Regional Governments of Peru
}

\author{
Martin M. Soto-Cordova ${ }^{1}$, Samuel León-Cárdenas ${ }^{2}$ \\ Kevin Huayhuas-Caripaza ${ }^{3}$ \\ Universidad de Ciencias y Humanidades, Lima, Peru
}

\author{
Raquel M. Sotomayor-Parian ${ }^{4}$ \\ Research Department \\ Universidad Autónoma de Ica, Ica, Peru
}

\begin{abstract}
This paper covers the problem of corruption in Peru, with an emphasis on regional governments, and presents a proposal for an anti-corruption software application architecture for those levels of government. The design of the proposal starts from the analysis of corruption encompassing statistical studies, trust evolution, government management, legal situation and incidents in information technology. Also, aspects of the budget allocation, crime data, political party financing data, management resources, contracting processes, integration systems and citizen participation are presented, for the subsequent presentation of the data structure and resources for the software application architecture. The methodology used is of an exploratory documentary type. In addition, a systemic approach and development are considered in three layers: data persistence, logical process, and presentation; considering the interrelationships that must exist between them for the development of the proposed architecture.
\end{abstract}

Keywords-Software architecture; anti-corruption; regional government; local government; corruption perception index

\section{INTRODUCTION}

Globally, corruption problems are a global concern because it is a multidimensional phenomenon that occurs systematically and at different levels and sectors of the countries [1]; which by misusing public or private power directly affects the development of countries, weakening governance, trust and rights of people. As defined universally and in the legal codes of Latin American nations, corruption is "the abuse of public power and the position for private benefit" [2].

Corruption materializes when there is a closed set of factors such as political, economic, cultural, social and axiological that influence the performance of officials, who easily fall for acts of corruption, such misuse of public funds mainly limits the effectiveness of social policies, strongly impacts the most vulnerable populations and allows the participation of illegal activities in the sphere of decision-making [3].

According to Transparency International, in the Corruption Perception Index (CPI) 2019, more than two thirds of the countries obtain scores lower than 50, with an average score of only 43. Denmark occupies the first place with the lowest corruption index worldwide. At the other extreme, the country with the highest perception of corruption is Somalia, the most corrupt since 6 years ago [4]. In the case of Peru, it registers a PCI equal to 35 out of 100 , which places it in the world ranking in $101^{\text {st }}$ place out of 180 countries, although Peru is above Brazil, Bolivia, Paraguay and Venezuela. However, it is still below the Latin American average as shown in Fig. 1.

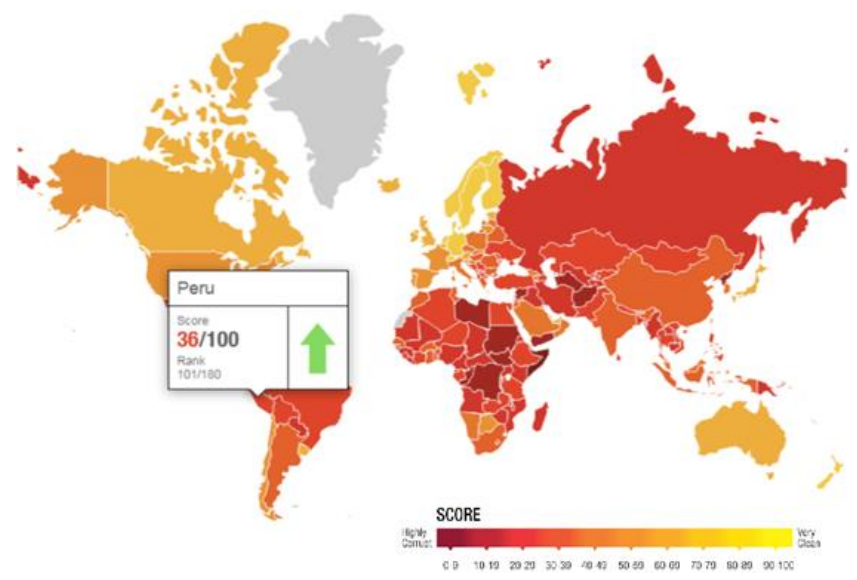

Fig. 1. Heat Map on the Corruption Perception Index 2019.

Although it is true, worldwide and predominantly Latin American, corruption problems are really worrying, however, in recent years, some countries have taken measures to mitigate this global problem. Organizational processes can be ISO 37000 anti-bribery certification based that consists of demonstrating the integrity of an organization and mitigating exposure to the risks of bribery [5].

According to Proética, a Peruvian chapter of Transparency International, $62 \%$ of the Peruvian population identifies corruption as one of the main problems in the country and $73 \%$ of the citizens consider that corruption will continue to increase in the next five years [6]. Perhaps motivated by impunity, the bad example of authorities of the highest rank and the perception that there are no effective sanctions; This triggers a general feeling in the population of high exposure to it, resignation, lack of mechanisms to eradicate it and therefore a great barrier to implement real and effective mechanisms to fight corruption.

In this context, information and communication technologies, data analytics and big data tools allow us to have the ability to predict, to emulate a reality and anticipate changes in the environment, using quantitative and qualitative methods to process the data and information available, in order to solve problems and predict relevant results in the fight 
against corruption $[7,8,9,10,11,12,13,14]$. Consequently, [15] discusses three questions aimed at public policy decisionmakers on the use of data, data science and new technologies to fight corruption: a) what data is important to prevent and Investigate acts of corruption? b) If they exist, how can data science be used to process them? and c) if a national or local government wants to adopt these alternatives, what actions should it take? Finally, policy recommendations are mentioned to governments in the region to make data-driven anticorruption initiatives and new technologies more effective.

Coding of the information system software requires determining the software architecture as a consequence of an analysis of the functionalities and processes of the governmental institutions of the regions of Peru, and the proposal of new processes and interrelations. Thus, this research covers the software architecture design that considers various regional government organizations, citizen participation and the use of information technologies related in an integrated way to achieve strengthening transparency in the management of regional governments and reducing corruption in those regions.

Therefore, this paper has the following structure: global context of IT as anticorruption tool, analysis of corruption in regional governments in Peru, resources and data for the anticorruption application architecture and proposal of the data structure and resources of the application architecture, additionally to results, conclusions and future work.

\section{CurRent ConteXt OF THE USE OF IT IN THE Fight AGAINST CORRUPTION IN THE WORLD}

In recent years, various countries have been incorporating ICT in government procurement processes, as well as mechanisms for public transparency of information. In this sense, a leading country is Estonia; who makes use of high technology and a transparent and available digital registration system, making it one of the least corrupt countries in the world [16].

There are some computer platforms developed to reduce corruption, such as GoAML (detection platform for money laundering networks) and GoINTEL (financial intelligence information exchange platform) developed by The United Nations (UN) [17]. Furthermore, in the European Union, Ukraine has an online procurement platform called ProZorro by simplifying oversight opportunities for the civil society and by enabling enhanced, open competition among businesses that aim to supply goods and services to the government entities. Likewise, The DoZorro artificial intelligence application was developed by Transparency International (Ukraine Chapter) in addition to the risk identifiers generated by the State Audit Service of Ukraine and serves to capture information from the electronic contracting national system ProZorro, to determine possible faults in the law or anomalies in the contracting processes and to identify tenders with a high risk of corruption [18]. Also, an early warning system for corruption in Spain based on neural networks was developed. This analyzes various data, such as property taxes, unemployment rate and number of years in government, etc.; and consequently it could predict corruption in the public sector and uncover hidden indicators of legal and economic problems including money laundering in the European Union [19].

In Latin America, an anti-corruption software, named IAC, was developed by The Comptroller of the province of $\mathrm{La}$ Guajira (Colombia) to measure the level of corruption in the institutions of the region, considering items such as accountability, customer service, among others. It could help the departmental administration, municipalities, educational institutions and all entities and that administer public resources to evaluate the country's management [20]. Also, the corruption risk algorithm was developed in Peru by the organization Ojo Público, named FUNES. This seeks links with companies to determine the possibility of winning in public procurement, managing to extract information from public databases on contracts made by the Peruvian government to investigate possible corruption risk scenarios and identify political and financial connections [21].

In some countries, mobile applications have been used mainly to instantly report corrupt acts. The "Action for Transparency (A4T)" app was launched by Transparency International in Uganda and Kenya that fights corruption and mismanagement of government funds. The citizen can to check the amount of government money pledged to each school and health clinic - and the amount actually spent [22]. Next, the "Bribr" app was launched by an entrepreneur in Russia, it allows the citizens to anonymously register and categorize bribes and show corruption problems [23]. Also, the "Transparencia al Instante" app was launched by the Transparency Unit of the City Hall of La Paz (Bolivia) to report acts of corruption or irregularities of the municipal public officials [24], and "Obras Transparentes" app launched by Ministry of Public Works, Services and Housing of Bolivia [25]. Also, the "Dilo Aquí Guate" app was launched in Guatemala by the Tigo Foundation and the NGO Acción Ciudadana. This allows confidential reporting of fraud, illicit enrichment, bribery, abuse of authority [26]. Furthermore, the "Denuncia la Corrupción Querétaro" app was launched in the city of Querétaro (Mexico), in order for citizens to participate in the mitigation of corruption. It includes a track mechanism for the complaint made [27]. Also, the "Elefantes Blancos" app launched by the government of Colombia. It seeks identify and track information about public construction works that have been neglected, abandoned or overbilled [28].

Particularly, in Peru has been implementing the National Policy for Integrity and the Fight against Corruption and other initiatives at the level of web-based technology platforms [29], although there is minimal use of information and communication technologies to mitigate this problem [30].

\section{ANALYSIS OF CORRUPTION IN REGIONAL GOVERNMENTS IN PERU}

Peru is governed by being a unitary and decentralized government; unitary, because it is a single entity with common duties and shared goals aimed at the general welfare or protection of citizens. It is also decentralized because Peruvian governance must be exercised at three levels of government: national government (also known as the central government), regional government, and local government (provincial and district municipalities). Decentralization, to that extent, is a 
democratic process and a permanent compulsory government policy whose objective is the integral development of the country [31]. However, part of the corruption problem has been increased and focused on regional governments (twenty five regions), this level of government that began its implementation since 2002 [32], in order to promote participatory decentralization in Peru, brought with it some positive aspects such as generating better development and quality of life for the inhabitants of its regions; however, due to the lack of policies, strategies and the due commitment of its officials, in several of the regions the different cases of corruption began to be identified [33, 34, 35].

According to the National Institute of Statistics and Informatics (INEI) of Peru, inquests in 2019, carried out on the perception of acts of corruption in Peruvian households by region [36], it was obtained that $4.2 \%$ of the households consulted reported that some member of their household was asked for an "extra payment" when making arrangements or requesting services in Public Institutions. Madre de Dios and the Lima region reported the highest percentages in "extra payments" of $8.8 \%$ and $7.9 \%$ respectively, while in Ayacucho $0.2 \%$ of households declared this situation; as shown in Fig. 2.

In turn, local governments constitute another level of government, which are made up of 196 provincial municipalities and 1,671 district municipalities, these governments have among their main functions: to comprehensively plan local development and territorial ordering, at the provincial level, thus how to permanently promote strategic coordination of comprehensive district development plans; Similar to regional governments, due to their autonomy to carry out activities in recent years, corruption cases in public services have increased [37, 38].

Fig. 3 shows the current situation and shows how the corruption network manifests at different levels of governments, emphasizing the corruption analysis in regional governments. The basic services or needs that citizens have are essential for the social development of Peruvians, it is there, where regional governments, through specialists, collect these needs to be evaluated and solved according to the problem. It is at this point where Public Investment Projects (PIP) are raised and the first incidents of corruption are perceived, where some consultants, public managers (Invierte.pe - National System of Multi-annual Programming and Investment Management) and advisers could present insufficient technical or managerial knowledge. Other incidents that exist are low resources and probably have officials without expertise. Furthermore, the procedures are cumbersome procedures with long duration in the management of the PIP.

The management of the PIPs is worked jointly between the Local Governments (LG) and the Regional Governments (RG) so that they can be managed in the technical areas of the ministries and approved by the Central Government (GC). However, it is here where the problem of corruption is exacerbated (see legend routes), where mayors, governors, use various media or intermediaries such as brokers, congressmen or government allies for the approval of the PIP; for this they use laws, regulations or addenda to misuse the economy of the Peruvian Government [39]. It is for this reason that the economic losses suffered by Peru due to corruption problems are around $10 \%$ of the annual public budget, exceeding three billion dollars. Therefore, it affects a tenth of the financial resources that are destined to health, infrastructure, administrative expenses, security, and education for the benefit of citizens.

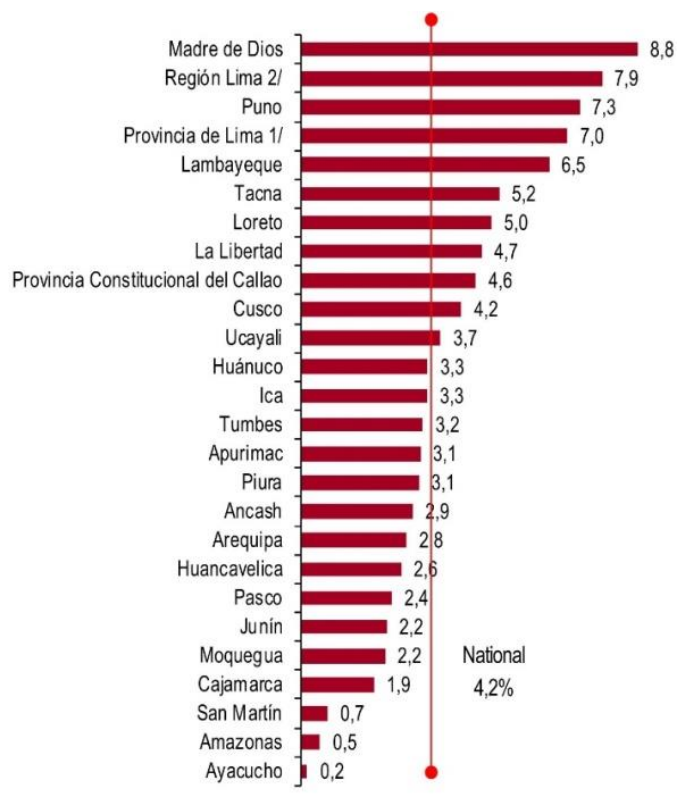

Fig. 2. Corruption Index in the Regions of Peru.

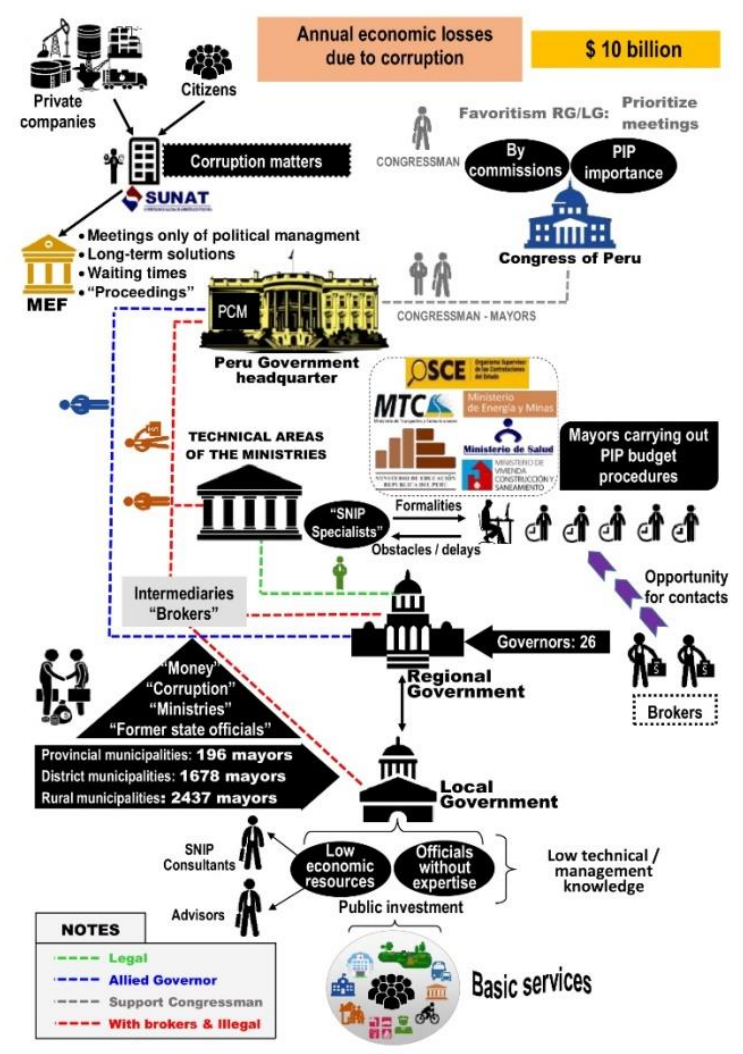

Fig. 3. Scenario of Interaction of the Players in the Corruption of the Regional Governments. 


\section{INTERACTION PROCESSESS FOR AN ANTI-CORRUPTION SYSTEM}

In the analysis of the current situation of corruption, it is highlighted that it has a high negative incidence in the national and regional government; affecting both its image, its management, and especially the population. Therefore, Fig. 4 shows the approach of an analysis model to reduce corruption for Regional Governments, using information technologies, positioning an anti-corruption application architecture module.

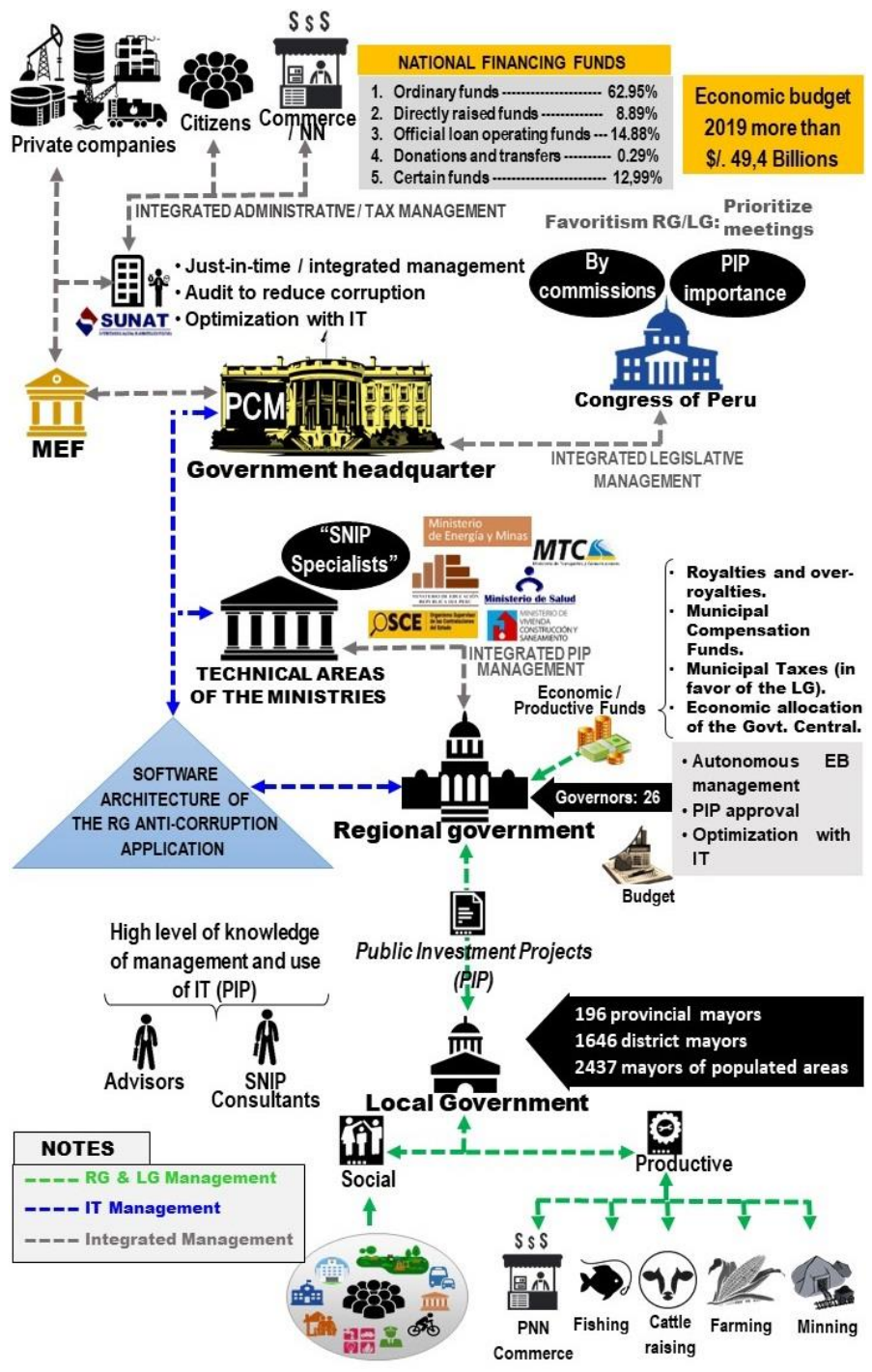

Fig. 4. Players and IT Interaction Scenario Against Corruption.

Due to the decentralization policy, the Office of the Presidency of the Council of Ministers (PCM) of the Government and the Ministry of Economy and Finance (MEF) annually agree funds to allocate to the Regional Governments, made up of transfers from the national government (from from all sources, that is, general resources, tax, royalties, customs revenues, etc.), financial income and own income from the collection of fees or rights. These funds should be directed to the development of the regions and promote science, technology and innovation. Therefore, these data are very important as input to the information system. Likewise, the technical areas of government ministries maintain a classification and prioritization of various areas within their field of action. So they interact with the Regional Governments to work together in the development of the regions. However, the Regional Governments have autonomy and under this operating framework corruption can potentially occur.

Currently, due to the low socio-economic situation of the majority of the population, the government prioritizes the management of basic services or to cover social needs, which are of high importance for the development of the regions. However, the productive management that Local Governments must have in conjunction with Regional Governments is being neglected in order to increase the regional contribution to national productivity, prioritize projects for the development of the region and promote activities related to science and technology. It should be noted that all this is minimized by the problem of corruption. In this situation, it is necessary to incorporate a module of the anti-corruption application architecture, to carry out a transparent management of the financial aspects and expected results in the various PIPs, and thus reduce the corruption index in the Regional Governments.

The resources and data considered to have an orientation in the architecture of the anti-corruption application for Regional Governments are the following:

- Budget allocation data for all Regional Governments.

- Corruption crime data.

- Financing data for political campaigns.

- Statistical resources or management information.

- Administrative management resources.

- Funds of the contracting processes in the Regional Governments.

- Integration resources between institutions.

- Funds for citizen participation in Regional Governments.

\section{DATa StRucture AND Resources of THE SOFTware ARCHITECTURE}

Fig. 5 shows the structure of data and resources for the development of the software architecture of the anti-corruption application. In order to operate and carry out information transparency action, the architecture must incorporate data from several sources as the National Office of Electoral Processes (ONPE) on the funds that political organizations use for their electoral campaigns, as well as data from Ministry of Justice of the judicial cases that are taking place and involving authorities and their family, friendship and business environments, from PCM on the transfer of funds for the regions from the central government, from the Supervisory Agency for State Procurement (OSCE) regarding procurement and contracting, and other data. On the other hand, it is very important to make the comparison with the information that comes from the Office of the Comptroller General of the Republic, since it is the institution in charge of controlling the country's public assets and resources. 


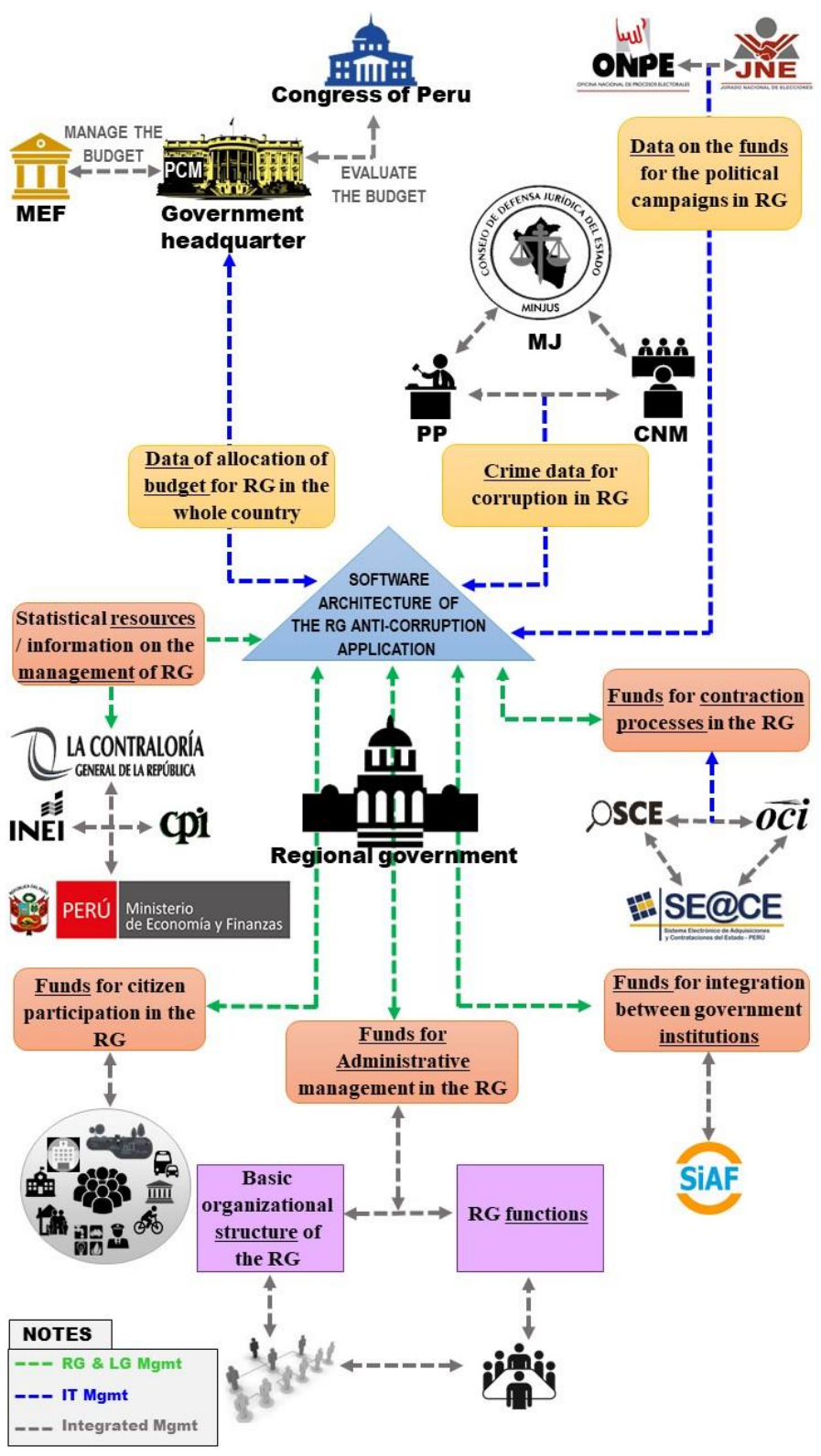

Fig. 5. Data and Resources for the Architecture.

For the development of the architecture of the anticorruption application, the approach is made to the levels of data processing and presentation. Therefore, it is considered that the following elements must be integrated:

\section{A. Data Processing Level}

- Budgets

- Financing

- Crimes
- Government contracts

- SIAF integration

- Administrative management (Regional Governments)

- Citizen participation

- Statistics / information from institutions. Regulators

\section{B. Presentation Level}

- Economic situation modulePolitical parties module

- Corruption module (court cases / Notifications)

- Contracting module (PIP notifications)

- Management module (reports, production and social)

- Partners (user registration - rating system)

- Citizen participation (services and transparency)

- News (give your opinion / vote, News and learn more)

Fig. 6 shows the software architecture, where the application database collects the data with relevant information for subsequent analysis, coming from the multiples resources (databases) from various organizations.

A key element in the anti-corruption enforcement is the transparency of government information. Therefore, through a Web service, all government information such as government budget, corruption statistics, budget, sources and activities of political organizations, government contracts and so on, is made publicly accessible.

At the logical processing level, data analytics and control of the information collected on the application server are performed. Before this, data analysis with a large volume of data is carried out, firstly to perform the capture, management and processing of data with low latency, and social networks can be added to add perceptions, complementary data, etc. In this way, artificial intelligence (AI) drives the complexity of the data through new forms and origins of the data. Advanced analytical techniques are incorporated, such as text analysis, machine learning, predictive analytics, data mining, statistics, after data conditioning.

Subsequently, correlations are found between them, the resulting information is prepared to show trends, summaries and comparisons of activities (works, investments, progress, etc.), budgets, government contracts and others. Thus, the adequate information can be made public for the population and available to the political authorities for better and more timely decisions. Likewise, it should be noted that public information through the Web service may be usable for academic research studies, interactive systems with the citizen, background monitoring of candidates and political and government authorities. 


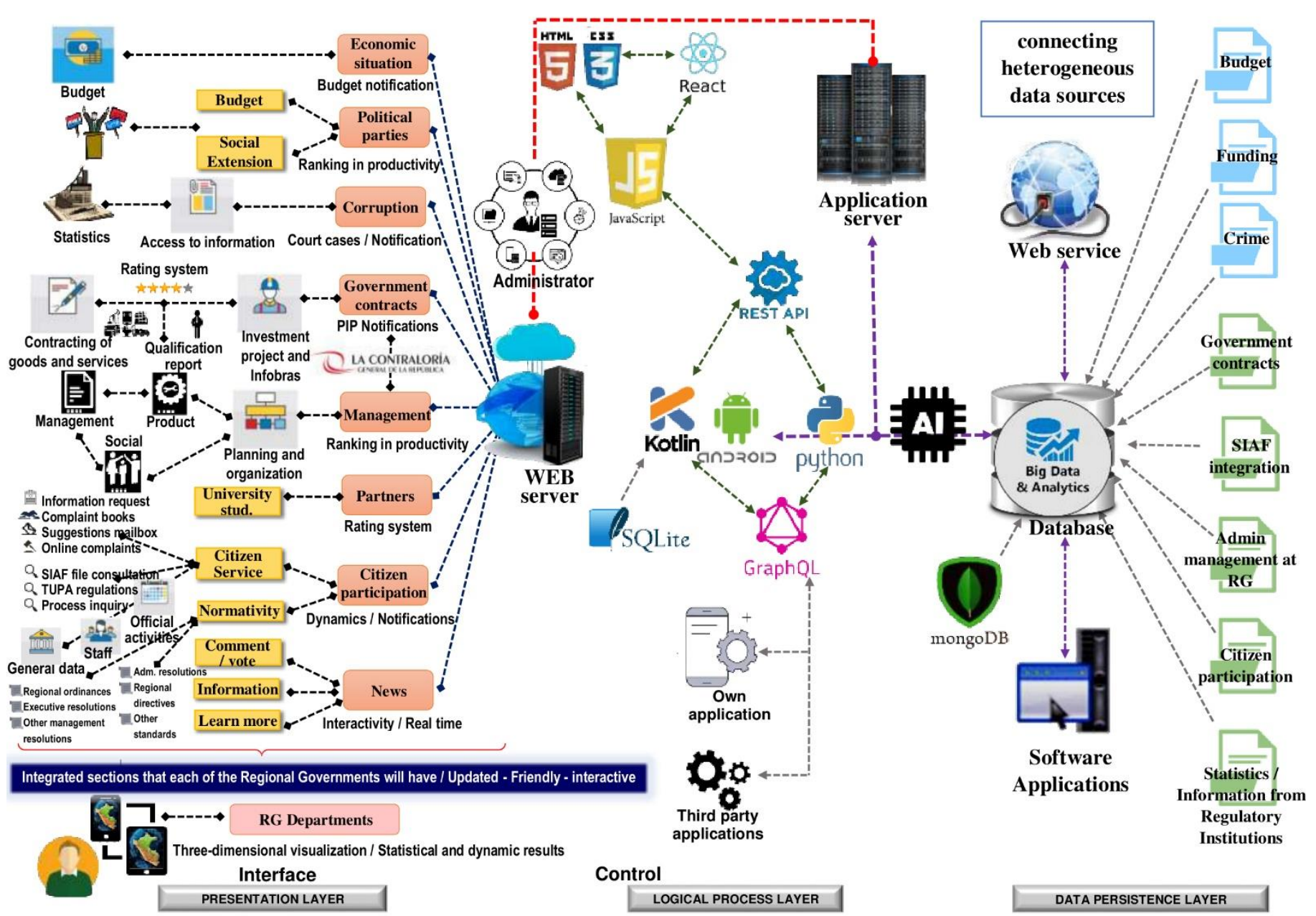

Fig. 6. Software Architecture Design.

\section{CONCLUSION AND FUTURE WORKS}

Corruption represents a systemic phenomenon, affects morale and ethics, generates discouragement in the population, affects the poorest population, and causes a large amount of resources to stop being used for project development, especially those aimed at closing gaps, serving the basic needs of the most neglected population. In this sense, an analysis of corruption in regional governments has been carried out from a current situation; considering statistical studies, management areas, legal aspects and incidents of the IT.

The resources and data necessary for the anti-corruption software architecture have been highlighted. Consequently, the structure of this architecture has been proposed considering data on budgets, crimes, financing, administrative management resources, government contracting processes, citizen participation, integration of institutions, statistics and information. Finally, the levels of presentation of the required modules, data processing and logic are established.

Given the susceptibility and complexity of the processes involved at the regional government level, it is considered that the implementation of the proposed software architecture is developed and implemented in phases, being able to integrate data analytics and machine learning tools to obtain greater precision of the indicators and medium and long-term projection for better decision making.

As new scenarios appear, such as the health emergency due to the COVID-19 pandemic, the conditions exist for other possible corruption mechanisms to appear. In this sense, the new modalities must be analyzed and the appropriate operations must be included to update the proposed architecture.

REFERENCES

[1] Neshkova, M. I., \& Kalesnikaite, V., "Corruption and citizen participation in local government: Evidence from Latin America", Governance Journal, Vol. 32, ํ4, pp. 677-693, Mar. 2019.

[2] Rotberg, R. I., "The Corruption of Latin America", chapter in book: Corruption in Latin America. How Politicians and Corporations Steal from Citizens, Springer, pp.1-25, Jan. 2019.

[3] Dammert, L., \& Sarmiento, K., "Corruption, Organized Crime, and Regional Governments in Peru", chapter in book: Corruption in Latin America. How Politicians and Corporations Steal from Citizens, Springer, pp.179-204, Jan. 2019.

[4] Transparency International. Corruption Perceptions Index 2019. 2020.

[5] International Organization for Standardization (ISO), ISO 37001 - AntiBribery Management Systems, 2016. [Online]. Available: https://www.iso.org. 
[6] Proética - Transparency International. "XI Encuesta Nacional sobre Percepciones de la Corrupción en el Perú”, Diciembre 2019.

[7] Fernando Martínez-Plumed, Juan Carlos Casamayor, Cèsar Ferri, Jon Ander Gómez, Eduardo Vendrell, "SALER: A Data Science Solution to Detect and Prevent Corruption in Public Administration", European Conference on Machine Learning and Knowledge Discovery in Databases (ECML PKDD), pp. 103-117, September 2018.

[8] Gasanova A., Medvedev A.N. and Komotskiy E.I., "The assessment of corruption impact on the inflow of foreign direct investment", 1st International Conference on Applied Mathematics and Computer Science (ICAMCS), January 2017.

[9] Noerlina et al., "Development of a Web Based Corruption Case Mapping Using Machine Learning with Artificial Neural Network", International Conference on Information Management and Technology (ICIMTech). pp. 400-405, November 2018.

[10] Kehler E., Paciello J. and Pane, J., "Anomaly Detection in Public Procurements using the Open Contracting Data Standard", 13th Alberto Mendelzon International Workshop on Foundations of Data Management (AMW), June 2019.

[11] Rabuzin K. and Modrušan N., "Prediction of public procurement corruption indices using machine learning methods"; 11th International Joint Conference on Knowledge Discovery, Knowledge Engineering and Knowledge Management (IC3K), pp. 333-340, September 2019.

[12] Popa, M., "Uncovering the structure of public procurement transactions", Business and Politics, Vol. 21, $\mathrm{N}^{\circ}$ 3, pp. 351-384, September 2019.

[13] Jiawei Li, Wen-Hao Chen, Qing Xu, Neal Shah and Timothy Mackey, "Leveraging Big Data to Identify Corruption as an SDG Goal 16 Humanitarian Technology", 9th Annual IEEE Global Humanitarian Technology Conference (GHTC), October 2019.

[14] Lima M.S.M.and Delen D., "Predicting and explaining corruption across countries: A machine learning approach", Government Information Quarterly, Vol. 37, $\mathrm{N}^{\circ}$ 1, January 2020.

[15] Cetina, C., Policy Brief \#9: Tres preguntas sobre el uso de los datos para luchar contra la corrupción. Corporación Andina de Fomento (CAF), Apr. 2020.

[16] Alvaro Treneman, Estonia, uno de los países menos corruptos gracias a la digitalización y la tecnología, Peru21, August 18, 2018. [Online]. Available: https://peru21.pe/economia/estonia-ejemplo-digitalizaciondesarrollo-tecnologico-421576-noticia/.

[17] United Nations, "UNODC's standard software system available for Financial Intelligence Units to counter Terrorist Financing and Money Laundering", July $2007 . \quad$ [Online]. Available: https://www.unodc.org/documents/treaties/COP2008/sideevents/ITS_Oct_9/goAML_brochure.pdf.

[18] Transparency International Ukraine, Dozorro Artificial Intelligence to Find Violations in Prozorro: How it works, November 2, 2018. [Online]. Available: https://ti-ukraine.org/en/news/dozorro-artificial-intelligenceto-find-violations-in-prozorro-how-it-works/.

[19] Félix J. López-Iturriaga and Iván Pastor Sanz, "Predicting Public Corruption with Neural Networks: An Analysis of Spanish Provinces", Social Indicators Resarch, Vol. 140, №3, pp. 975-998, December 2018.

[20] La Guajira Hoy (LGH), Creado en Riohacha un Software anticorrupción IAC, January 17, 2015. [Online] Available: https://laguajirahoy.com/2015/01/creado-en-riohacha-un-software.html.

[21] Paola Nalvarte, "Peruvian investigative site Ojo Público develops algorithm to track possible acts of corruption", Journalism in the Americas, December 2019. [Online] Available: https://knightcenter.utexas.edu/blog/00-21439-peruvian-investigativesite-ojo-publico-develops-algorithm-track-possible-acts-corrupt.
[22] Transparency International, Action for Transparency, 2017. [Online]. Available: https://tikenya.org/action-for-transparency/.

[23] Alexandra Nikolchev, Bribr: A new Russian anti-corruption app, December 13, 2012. [Online]. Available: https://www.pbs.org/wnet /need-to-know/the-daily-need/bibr-a-new-russian-anti-corruptionapp $/ 15709 /$.

[24] LATINNO - Innovations for Democracy in Latin America, Instant Transparency, 2020. [Online]. Available: https://latinno.net/ en/case/2129/.

[25] Los Tiempos, Ministro Arias presenta aplicación móvil para realizar denuncias y reclamos de corrupción, February 07, 2020. [Online]. Available: https://www.lostiempos.com/actualidad/pais/20200207/ ministro-arias-presenta-aplicacion-movil-realizar-denuncias-reclamos.

[26] Redación Tecno, Lanzan app para denunciar actos de corrupción, Prensa Libre, Enero 14, $2016 . \quad$ [Online]. Available: https://www.prensalibre.com/vida/tecnologia/lanzan-app-paradenunciar-actos-de-corrupcion/.

[27] Antonio Cahun, Querétaro ya cuenta con app propia para denunciar la corrupción, Xataka México, June 22, 2016. [Online]. Available: https://www.xataka.com.mx/aplicaciones/queretaro-ya-cuenta-con-apppropia-para-denunciar-la-corrupcion.

[28] Jennifer Guay, Colombia's anti-corruption app identifies $\$ 163 \mathrm{~m}$ in neglected projects, June 19, 2017. [Online]. Available: https://apolitical.co/en/solution_article/colombias-anti-corruption-appidentifies-163m-neglected-projects.

[29] Presidencia del Consejo de Ministros (PCM). Política Nacional de Integridad y Lucha Contra la Corrupción. Sep. 2017.

[30] Defensoría del Pueblo, Reporte de la Corrupción en el Perú №2 - El Sistema Anticorrupción Peruano: Diagnóstico y Desafíos, Dec. 2017.

[31] Presidencia de Consejo de Ministros, “Aspectos Claves en la Gestión Pública Descentralizada”, 2011.

[32] Montenegro, V. C., "Análisis de la incidencia de la corrupción en el desarrollo regional del Perú", Rev. Tradición, Segunda época (Universidad Ricardo Palma) Nº19, pp. 128-141, 2019.

[33] Mc Nulty, S. L., \& Garcia, G. G., "Politics and Promises: Exploring Fifteen Years of Peru's Participatory Decentralization Reform", Public Organization Review, Vol. 19, N4, pp. 45-64, Aug. 2018.

[34] Vega Luna, E. E., Ayay, E., Yalú, L., \& Quiñones Huayna, N. M., Guía para elaborar un plan de integridad y lucha contra la corrupción en los gobiernos regionales y municipales. Nov. 2019.

[35] Valerio, C. M., \& Ramírez, W. P., "Análisis de la tipificación de la corrupción privada en el Perú: ¿Una estrategia global contra la corrupción también debe involucrar a los particulares?;Y Y as empresas?", Rev. IUS et Veritas (Pontificia Universidad Católica del Perú), N58, pp. 32-54, 2019.

[36] Instituto Nacional de Estadística e Informática (INEI), Informe Técnico: Perú: Percepción Ciudadana sobre Gobernabilidad, Democracia y Confianza en las Instituciones, Julio-Diciembre 2019. ํㅜ 1, Feb. 2020.

[37] OECD, OECD Public Governance Reviews: Peru: Integrated Governance for Inclusive Growth, OECD Publishing, 2016.

[38] Rollón, M. L. R., \& García, F. J. Á., "El control de la corrupción en América Latina: agenda política, judicialización e internacionalización de la lucha contra la corrupción", Documento de trabajo (Fundación Carolina), $\mathrm{N}^{\circ} 11,2^{\mathrm{a}}$ época, 2019.

[39] López Tello, Karen. "La microcorrupción de cada día", May. 19, 2017. [Online]. Available: http://www.idl-reporteros.pe/la-microcorrupcionde-cada-dia/. 